University of Nebraska - Lincoln

DigitalCommons@University of Nebraska - Lincoln

Public Health Resources

Public Health Resources

2004

\title{
WIF-B Cells as a Model for Alcohol-Induced Hepatocyte Injury
}

Courtney S. Schaffert

The Department of Veterans Affairs Medical Center, University of Nebraska Medical Center, Omaha, NE, USA

Sandra L. Todero

The Department of Veterans Affairs Medical Center, University of Nebraska Medical Center, Omaha, NE, USA

Benita L. McVicker

The Department of Veterans Affairs Medical Center, University of Nebraska Medical Center, Omaha, NE, USA

Pamela L. Tuma

The Department of Biology, The Catholic University of America, Washington, DC, USA

Michael F. Sorrell

The Department of Veterans Affairs Medical Center, University of Nebraska Medical Center, Omaha, NE, USA

See next page for additional authors

Follow this and additional works at: https://digitalcommons.unl.edu/publichealthresources

Part of the Public Health Commons

Schaffert, Courtney S.; Todero, Sandra L.; McVicker, Benita L.; Tuma, Pamela L.; Sorrell, Michael F.; and Tuma, Dean J., "WIF-B Cells as a Model for Alcohol-Induced Hepatocyte Injury" (2004). Public Health Resources. 88.

https://digitalcommons.unl.edu/publichealthresources/88

This Article is brought to you for free and open access by the Public Health Resources at DigitalCommons@University of Nebraska - Lincoln. It has been accepted for inclusion in Public Health Resources by an authorized administrator of DigitalCommons@University of Nebraska - Lincoln. 


\section{Authors}

Courtney S. Schaffert, Sandra L. Todero, Benita L. McVicker, Pamela L. Tuma, Michael F. Sorrell, and Dean J. Tuma 


\title{
WIF-B cells as a model for alcohol-induced hepatocyte injury
}

\author{
Courtney S. Schaffert ${ }^{\mathrm{a}, \mathrm{b}}$, Sandra L. Todero ${ }^{\mathrm{a}}$, Benita L. McVicker ${ }^{\mathrm{a}}$, \\ Pamela L. Tuma ${ }^{c}$, Michael F. Sorrell ${ }^{\mathrm{a}, \mathrm{b}}$, Dean J. Tuma, ${ }^{\mathrm{a}, \mathrm{b}, *}$ \\ ${ }^{a}$ The Department of Veterans Affairs Medical Center, University of Nebraska Medical Center, Omaha, NE, USA \\ ${ }^{\mathrm{b}}$ The Department of Internal Medicine, University of Nebraska Medical Center, Omaha, NE, USA \\ ${ }^{\mathrm{c}}$ The Department of Biology, The Catholic University of America, Washington, DC, USA
}

Received 2 January 2004; accepted 27 January 2004

\begin{abstract}
A potential in vitro model for studying the mechanisms of alcohol-induced hepatocyte injury is the WIF-B cell line. It has many hepatocyte-like features, including a differentiated, polarized phenotype resulting in formation of bile canaliculi. The aim of this study was to examine the effects of ethanol treatment on this cell line. WIF-B cells were cultured up to $96 \mathrm{~h}$ in the absence or presence of $25 \mathrm{mM}$ ethanol and subsequently were analyzed for ethanol-induced physiological and morphological changes. Initial studies revealed WIF-B cells exhibited alcohol dehydrogenase (ADH) activity, expressed cytochrome P4502E1 (CYP2E1), and efficiently metabolized ethanol in culture. This cell line also produced the ethanol metabolite acetaldehyde and exhibited low $K_{\mathrm{m}}$ aldehyde dehydrogenase (ALDH) activity, comparable to hepatocytes. Ethanol treatment of the WIF-B cells for $48 \mathrm{~h}$ led to significant increases in the lactate/pyruvate redox ratio and cellular triglyceride levels. Ethanol treatment also significantly altered WIF-B morphology, decreasing the number of bile canaliculi, increasing the number of cells exhibiting finger-like projections, and increasing cell diameter. The ethanol-induced changes occurring in this cell line were negated by addition of the ADH inhibitor, 4-methylpyrazole (4-MP), indicating the effects were due to ethanol metabolism. In summary, the WIF-B cell line metabolizes ethanol and exhibits many ethanol-induced changes similar to those found in hepatocytes. Because of these similarities, WIF-B cells appear to be a suitable model for studying ethanol-induced hepatocyte injury.
\end{abstract}

Keywords: WIF-B cells; Alcohol dehydrogenase; Triglycerides; Ethanol metabolism; Liver injury; Cytochrome P4502E1

\section{Introduction}

The deleterious effects of alcohol abuse are characterized by appearance of fatty liver, hepatocyte necrosis, fibrosis, and ultimately cirrhosis [1]. The mechanisms behind these pathological effects are unclear, but appear to be mediated mainly by ethanol metabolism. Elucidation of the mechanisms leading to ethanol-induced hepatic injury has been hampered by a lack of appropriate in vitro models. Establishment of a hepatocyte culture system to accomplish such mechanistic studies would be ideal; however, limitations in culturing hepatocytes have hindered progress in this area. In conventional culture, hepatocytes

\footnotetext{
Abbreviations: ADH, alcohol dehydrogenase; ALDH, aldehyde dehydrogenase; CYP2E1, cytochrome P4502E1; 4-MP, 4-methylpyrazole

*Corresponding author. Tel.: +1-402-346-8800x3548; fax: +1-402-449-0604

E-mail address: dean@tuma.net (D.J. Tuma).
}

exhibit early phenotypic changes leading to a decrease or loss of many liver-specific phenomena, including expression of alcohol dehydrogenase (ADH) and ethanol metabolism $[2,28]$. In attempts to elucidate effects of ethanol metabolism on hepatocyte injury, other hepatic and nonhepatic cell lines have been utilized [3-6], but these cell lines are limited in their similarities to hepatocytes, both in morphology and function.

In view of the limitations of previously used culture systems for mechanistic studies of ethanol-induced hepatotoxicity, the WIF-B cell line was studied as a possible model. The WIF-B cell line is a highly differentiated and polarized rat hepatoma hybrid, which forms bile canaliculi-like structures [7]. This cell line has been reported as a good in vitro model for studying many hepatocyte-specific phenomena, such as hepatocyte polarity [8,9], protein secretion [7], bile acid transport [10], intercellular communication [11], and protein transport [12]. This cell line is also stable over many passages [13]. 
To determine the usefulness of the WIF-B cell line as a model for ethanol-induced hepatocyte injury, this study investigated the activities of ADH and aldehyde dehydrogenase (ALDH), ethanol metabolism, and acetaldehyde production. This study also examined the activity and level of cytochrome P4502E1 (CYP2E1), lactate/pyruvate redox ratios, cellular triglyceride levels, and morphological changes caused by ethanol metabolism.

\section{Materials and methods}

\subsection{Materials}

F-12 Coon's modified culture medium, medium supplements, UV triglyceride assay kit, lactate assay kit, pyruvate assay kit, and horse radish peroxidase-conjugated antirabbit secondary antibody were from Sigma Chemical Co. Fetal bovine serum was from Hyclone. Rabbit antiCYP2E1 polyclonal antibody was from Calbiochem. All other materials were of reagent grade.

\subsection{Hepatocyte isolation}

Hepatocytes from chow-fed rats were isolated as previously described [30]. Hepatocyte viability was determined by trypan blue exclusion and was routinely greater than $90 \%$.

\subsection{Cell culture}

WIF-B cells were a generous gift from Dr. Ann L. Hubbard (Johns Hopkins University School of Medicine, Baltimore, MD, USA) and were cultured as described by Cassio et al. [14]. Cells were routinely passaged at day 7 for propagation at $1.3 \times 10^{4} \mathrm{cells} / \mathrm{cm}^{2}$. For experiments, cells were plated at a density of $1.6 \times 10^{4}$ to $1.9 \times 10^{4}$ cells $/ \mathrm{cm}^{2}$. WIF-B cells at approximately $80 \%$ confluence (day 9 or 10) were cultured up to $96 \mathrm{~h}$ in the presence or absence of $25 \mathrm{mM}$ ethanol and/or 4-methylpyrazole (4-MP). At the beginning of each experiment, the media was supplemented with $10 \mathrm{mM}$ HEPES, pH. 7.0. The dishes were sealed with two layers of parafilm and incubated for the specified times. Except for the ethanol metabolism and acetaldehyde production studies, all experiments performed at 72 or $96 \mathrm{~h}$ were given one media change at $48 \mathrm{~h}$ and were then resealed. Experiments were performed successfully through 10 passages.

\subsection{Ethanol metabolism}

Ethanol metabolism studies were performed as described previously [3], using media from WIF-B cells incubated in the presence or absence of $25 \mathrm{mM}$ ethanol up to $96 \mathrm{~h}$. Ethanol and acetaldehyde concentrations were determined by headspace gas chromatography [15].

\section{5. $A D H$ and $A L D H$ activities}

WIF-B cells were incubated up to $96 \mathrm{~h}$ in the presence or absence of $25 \mathrm{mM}$ ethanol as described above. At specific times, the media was removed and the cells were washed with PBS, pH 7.4. The cells (approximately $1.5 \times 10^{6}$ cells/ $60 \mathrm{~mm}$ dish) were lysed with $400 \mu \mathrm{l}$ of $1 \%$ Triton X-100 in $\mathrm{H}_{2} \mathrm{O}$ and sonicated with a Branson sonifier. As a comparison, lysates from freshly isolated hepatocytes were prepared in a similar manner. ADH and ALDH activities were determined as described previously [3].

\subsection{Triglyceride extraction and analysis}

Extraction of triglycerides was performed essentially as described by Folch et al. [17]. After exposure to $25 \mathrm{mM}$ ethanol for 48 or $96 \mathrm{~h}$, WIF-B cells (approximately $5 \times 10^{6}$ cells $/ 100 \mathrm{~mm}$ dish) were rinsed with PBS, $\mathrm{pH}$ 7.4 , and were harvested by scraping. The cells were collected at $1000 \mathrm{rpm}$ and the pellet was sonicated in PBS, pH 7.4. Five volumes of chloroform:methanol (2:1) was added to the sonicated material to extract the triglycerides. The triglyceride content was determined using the UV triglyceride assay kit according to manufacturer's instructions. The cell number was determined on an aliquot of the original sonicate by DNA quantification [18].

\subsection{Cellular redox state}

The WIF-B cellular redox state was determined by examining the concentrations of lactate and pyruvate in the culture medium as described previously [4]. WIF-B cells were incubated in the presence or absence of $25 \mathrm{mM}$ ethanol and at specific times the media was collected. The protein was precipitated with trichloroacetic acid (7\% final concentration) and the soluble fraction was analyzed using lactate and pyruvate assay kits according to the manufacturer's instructions.

\subsection{Preparation of microsomes}

WIF-B cells incubated for $96 \mathrm{~h}$ in the presence or absence of $0.5 \mathrm{mM} 4-\mathrm{MP}$ were harvested by scraping. The cell suspension was sonicated and microsomes were prepared by differential centrifugation. Microsomal pellets were resuspended in PBS, pH 7.4, containing 20\% glycerol. Protein content was determined according to the method of Lowry et al. [16]. Microsomes were also prepared from freshly isolated hepatocytes for comparison.

\section{9. p-Nitrophenol oxidation assay}

Microsomal proteins (50-200 $\mu \mathrm{g}$ ) from hepatocytes and WIF-B cells were analyzed for CYP2E1 activity as previously described by $\mathrm{Wu}$ and Cederbaum [19]. 


\subsection{Immunoblot analysis of CYP2E1 expression}

Immunoblots were prepared as described previously [20] using $10 \%$ sodium dodecyl sulfate-polyacrylamide gel electrophoresis and loading $4 \mu \mathrm{g}$ of microsomal protein from hepatocytes and WIF-B cells. The blots were blocked for $1 \mathrm{~h}$ at $37^{\circ} \mathrm{C}$ in Blotto (PBS, pH 7.4, 0.05\% Tween-20, $5 \%$ nonfat dry milk), then were incubated overnight at $4{ }^{\circ} \mathrm{C}$ with a rabbit anti-CYP2E1 polyclonal antibody. The blots were washed and incubated for $1 \mathrm{~h}$ at $25^{\circ} \mathrm{C}$ with horse radish peroxidase-conjugated anti-rabbit secondary antibody. Blots were washed thoroughly, developed using enhanced chemiluminescence, and exposed to film. Densitometric analyses were performed using a Molecular Dynamics Personal Densitometer SI and Image QuaNT software.

\subsection{Quantification of morphological phenomena}

WIF-B cells were examined under phase contrast at $20 \times$ magnification using a Nikon TMS inverted microscope. The cell number, the number of bile canaliculi, and the number of cells with projections were counted. Three random fields consisting of at least 150 cells per field were counted for each experimental condition, with a minimum of four experiments analyzed. Cell and nuclei diameters were measured using the Scion Image program (public domain image analysis software, Scion Corporation). Estimating the nuclei at $10 \mu \mathrm{m}$, the cell diameters were converted to micrometers, and were reported as such.

\subsection{Statistical analysis}

Results were expressed as mean \pm S.E.M. Comparisons between untreated and ethanol-treated WIF-B cells were made with the Student's $t$ test for paired data; $P \leq 0.05$ was considered significant. Comparisons among three groups of data were made using a one-way ANOVA with the Tukey's post hoc test; $P \leq 0.05$ was considered significant.

\section{Results}

Initially, WIF-B cells were examined for ADH activity and ethanol metabolism. WIF-B cells had approximately twice the ADH activity of freshly isolated hepatocytes, based on equal protein amounts assayed (Table 1). This activity did not change significantly through 10 passages. The ability of the WIF-B cells to metabolize ethanol in culture was then investigated. As shown in Fig. 1A, the concentration of ethanol decreased in a linear fashion through $96 \mathrm{~h}$. To ensure the clearance of ethanol was due to its metabolism, a potent inhibitor of ADH and CYP2E1, 4-MP, was added at the onset of the experiments. Addition of $0.5 \mathrm{mM} 4-\mathrm{MP}$ was sufficient to inhibit ethanol clearance (Fig. 1A). Analysis of ADH activity in WIF-B cells showed no significant change due to exposure to ethanol (Table 1).

Ethanol metabolism in hepatocytes produces acetaldehyde, an extremely reactive compound implicated in ethanol-induced hepatocyte injury [21-23]. The production of acetaldehyde by the WIF-B cells was then investigated. Acetaldehyde was detectable $1 \mathrm{~h}$ after addition of ethanol (approximately $20 \mu \mathrm{M}$ ), reached a maximum concentration at $6 \mathrm{~h}$ (approximately $40 \mu \mathrm{M}$ ), but decreased to basal levels by $48 \mathrm{~h}$ (Fig. 1B). These results are in accordance with previous reports analyzing acetaldehyde levels in freshly isolated hepatocytes $[24,25]$. The production of acetaldehyde was inhibited by the addition of $0.5 \mathrm{mM}$ 4MP, indicating the acetaldehyde produced was from ethanol metabolism. The low amount of acetaldehyde observed in freshly isolated hepatocytes cultured in the presence of ethanol is in part, due to its metabolism by cellular ALDH enzymes, particularly the low $K_{\mathrm{m}} \mathrm{ALDH}$ (reviewed in Ref. [27]). To explain the low and transient acetaldehyde concentrations in the WIF-B cells, the cellular ALDH activities were examined. Although WIF-B cells had approximately half the total ALDH activity found in hepatocytes, these two cell types had roughly the same activities of the low $K_{\mathrm{m}}$ ALDH (Table 1). While the low $\mathrm{Km}$ ALDH activity in ethanol-treated WIF-B cells decreased significantly over $96 \mathrm{~h}$ compared to $t_{0}$, the

Table 1

Comparison of ADH and ALDH activities between WIF-B cells and hepatocytes

\begin{tabular}{|c|c|c|c|}
\hline Sample $(n=4)$ & ADH activity & Total ALDH activity & Low $K_{\mathrm{m}}$ ALDH activity \\
\hline WIF-B $\left(t_{0}\right)$ & $26.39 \pm 3.03$ & $7.96 \pm 1.36$ & $3.41 \pm 0.32$ \\
\hline C WIF-B (48 h) & $22.99 \pm 1.52$ & $8.76 \pm 0.73$ & $2.86 \pm 0.15$ \\
\hline E WIF-B (48 h) & $24.04 \pm 0.56$ & $8.17 \pm 0.81$ & $2.54 \pm 0.29$ \\
\hline C WIF-B (96 h) & $19.38 \pm 2.25$ & $6.77 \pm 1.07$ & $2.47 \pm 0.19$ \\
\hline E WIF-B (96 h) & $20.43 \pm 2.40$ & $5.28 \pm 0.91$ & $1.43 \pm 0.32^{\mathrm{a}}$ \\
\hline Fresh rat hepatocytes & $14.05 \pm 0.63^{\mathrm{a}}$ & $14.26 \pm 1.77^{\mathrm{a}}$ & $2.86 \pm 0.54$ \\
\hline
\end{tabular}

Lysates from WIF-B cells at days 9-10 of culture $\left(t_{0}\right)$ were compared to those from freshly isolated rat hepatocytes for ADH and ALDH activities. To determine if ethanol treatment affected these activities, WIF-B cells were incubated in the absence (C WIF-B) or presence (E WIF-B) of 25 mM ethanol for 48 or $96 \mathrm{~h}$, then lysates from these conditions were analyzed. All activities are expressed as nanomoles of NAD ${ }^{+}$oxidized/min/mg protein and are shown as the mean \pm S.E.M. All determinations were performed in duplicate for each of the four samples.

${ }^{a}$ Values significantly different from the corresponding WIF-B $\left(t_{0}\right) ; P<0.05$. 

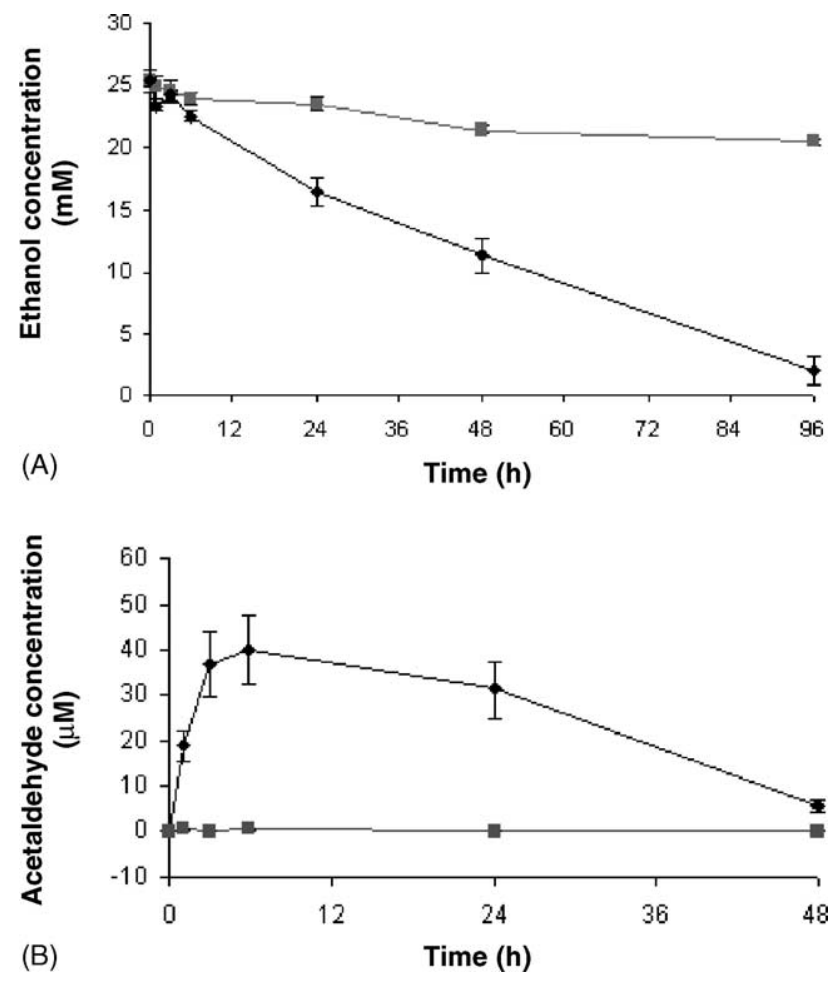

Fig. 1. Ethanol metabolism and acetaldehyde production by WIF-B cells. WIF-B cells were treated with $25 \mathrm{mM}$ ethanol up to $96 \mathrm{~h}$. The concentration of ethanol (A) or acetaldehyde (B) in the media of WIF-B cells in the absence $(\boldsymbol{)})$ or presence $(\boldsymbol{\square})$ of $0.5 \mathrm{mM}$ 4-MP was analyzed. Media samples were removed at designated times and ethanol and acetaldehyde concentrations were determined by headspace gas chromatography. Data are expressed as the mean \pm S.E.M. of four separate experiments.

activity from the ethanol-treated cells was not significantly different from control cells incubated $96 \mathrm{~h}$ (Table 1).

CYP2E1, a cytochrome P450 enzyme implicated in ethanol-induced liver injury, was also examined in the WIF-B cells. Immunoblot analysis using an anti-CYP2E1 antibody revealed that the WIF-B cell microsomes had approximately $25 \%$ the level of CYP2E1 found in hepatocyte microsomes (Fig. 2). Incubation of WIF-B cells with $0.5 \mathrm{mM}$ 4-MP for $96 \mathrm{~h}$ increased the level of CYP2E1 to approximately $65 \%$ of that in hepatocytes. These levels were consistent with CYP2E1 activity observed using the $p$-nitrophenol oxidation assay. CYP2E1 activity from chow hepatocyte microsomes was $1.36 \pm 0.09 \mathrm{nmol} / \mathrm{mg} / \mathrm{min}$ while the activity from WIF-B microsomes was $0.36 \pm 0.11 \mathrm{nmol} / \mathrm{mg} / \mathrm{min}$ (approximately $26 \%$ of the activity found in chow hepatocytes). Incubation for $96 \mathrm{~h}$ with 4-MP increased the activity in the WIF-B microsomes to $0.87 \pm 0.25 \mathrm{nmol} / \mathrm{mg} / \mathrm{min}$ (approximately $64 \%$ of the activity in chow hepatocytes; $n=4$ ).

Metabolism of ethanol by ADH and acetaldehyde by ALDH generates NADH, resulting in a reduced redox state in hepatocytes (reviewed in Ref. [39]). To determine the effects of ethanol metabolism on the WIF-B cellular redox state, these cells were cultured up to $96 \mathrm{~h}$ in the absence or presence of $25 \mathrm{mM}$ ethanol. A marked increase in the lactate/pyruvate $\left(\mathrm{NADH} / \mathrm{NAD}^{+}\right.$) ratio was observed after
1

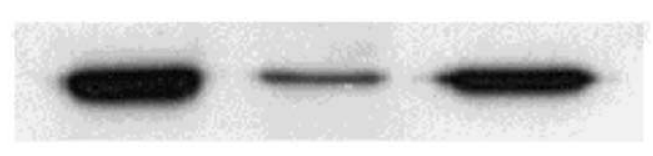

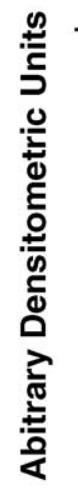

100
80
60
40
20
0
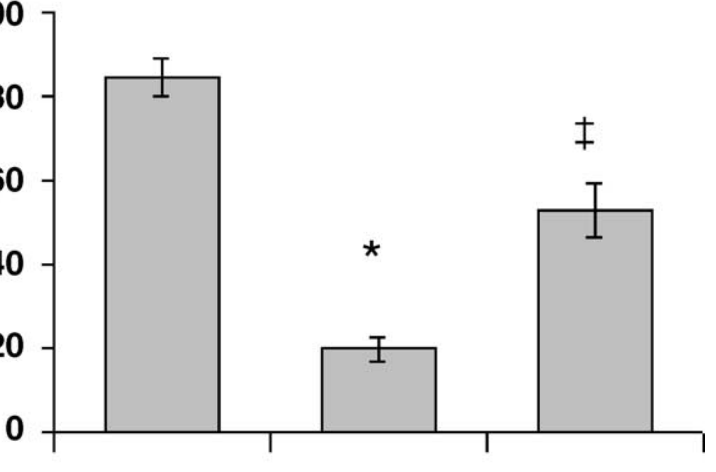

3

Fig. 2. CYP2E1 expression in WIF-B cells. Microsome preparations (4 $\mu \mathrm{g}$ protein per lane) were analyzed by immunoblotting and densitometry as described in Section 2. 1, freshly isolated hepatocytes; 2, WIF-B cells harvested at 9 days of culture; 3 , WIF-B cells treated $96 \mathrm{~h}$ with $0.5 \mathrm{mM} \mathrm{4-}$ MP and harvested at day 9. Data are expressed as the mean \pm S.E.M. of four separate experiments. ${ }^{*}, 2$ is significantly different from 1 and 3 ; $P<0.01$. $\ddagger, 3$ is significantly from 1 and $2 ; P<0.01$.

ethanol exposure for all times examined (Fig. 3). Incubation of these cells in the presence of $25 \mathrm{mM}$ ethanol and $0.5 \mathrm{mM}$ 4-MP completely reversed the ethanol-induced change in redox state (data not shown). These results are in accordance with those obtained from other cell lines transfected with ADH [4,5] and those obtained from isolated hepatocytes [24].

WIF-B cells were incubated in the presence or absence of $25 \mathrm{mM}$ ethanol for 48 or $96 \mathrm{~h}$, and were examined for cellular triglyceride levels. By $48 \mathrm{~h}$, the level of triglycerides in the ethanol-treated cells was elevated approximately threefold over the control level (Fig. 4). A similar elevation was observed after $96 \mathrm{~h}$ (data not shown). Addition of $0.5 \mathrm{mM} 4-\mathrm{MP}$ reversed the ethanol-induced increase in triglyceride content (Fig. 4), indicating that the accumulation of triglycerides was a result of ethanol metabolism. These data are in accordance with the development of fatty liver in hepatocytes isolated from rats chronically fed an ethanol-containing diet $[26,27]$.

An important structural feature of mature WIF-B cells is the presence of bile canaliculi. After incubation of mature WIF-B cells with $25 \mathrm{mM}$ ethanol for $48 \mathrm{~h}$, a number of morphological differences were observed. Cells incubated with $25 \mathrm{mM}$ ethanol exhibited 33\% fewer bile canaliculi, a threefold increase in the number of cells with lamellipodia and filopodia, and a 1.2-fold increase in cell diameter and the cells appeared less uniform in shape than control cells (Table 2, Fig. 5A and B). Similar results were obtained with $50 \mathrm{mM}$ ethanol (Fig. 5C). Addition of $0.5 \mathrm{mM}$ 4-MP inhibited the ethanol-induced morphological changes 


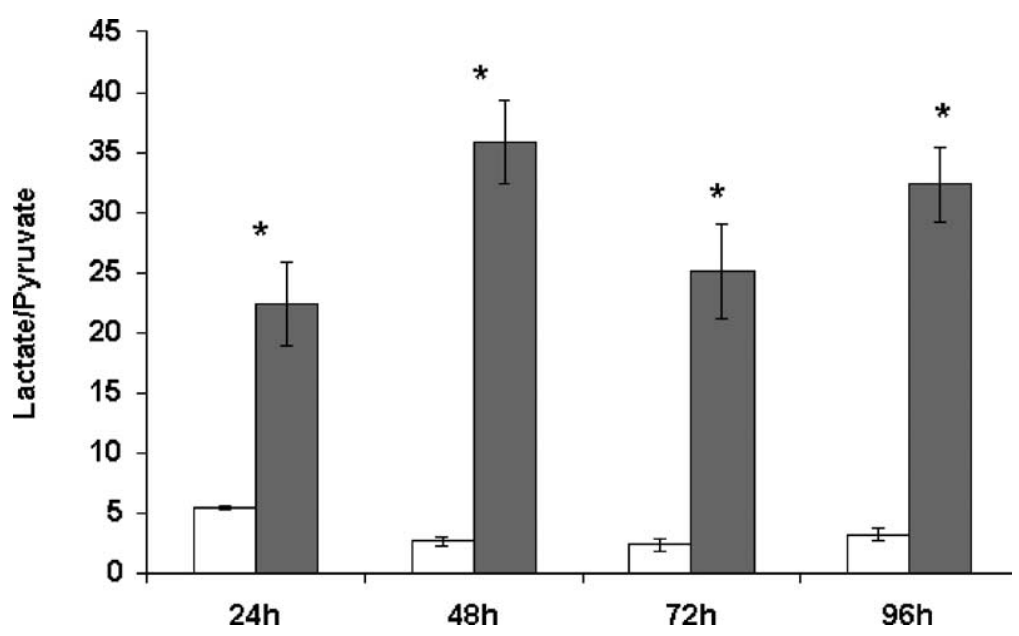

Fig. 3. Ethanol-induced increase in reduced redox ratio in WIF-B cells. WIF-B cells were cultured in the absence (open bars) or presence (solid bars) of $25 \mathrm{mM}$ ethanol for the times indicated. The cellular redox state was determined as described in Section 2. Data are expressed as the mean lactate/pyruvate $\left(\mathrm{NADH} / \mathrm{NAD}^{+}\right)$ratio \pm S.E.M. from four separate experiments. ${ }^{*} P<0.01$.

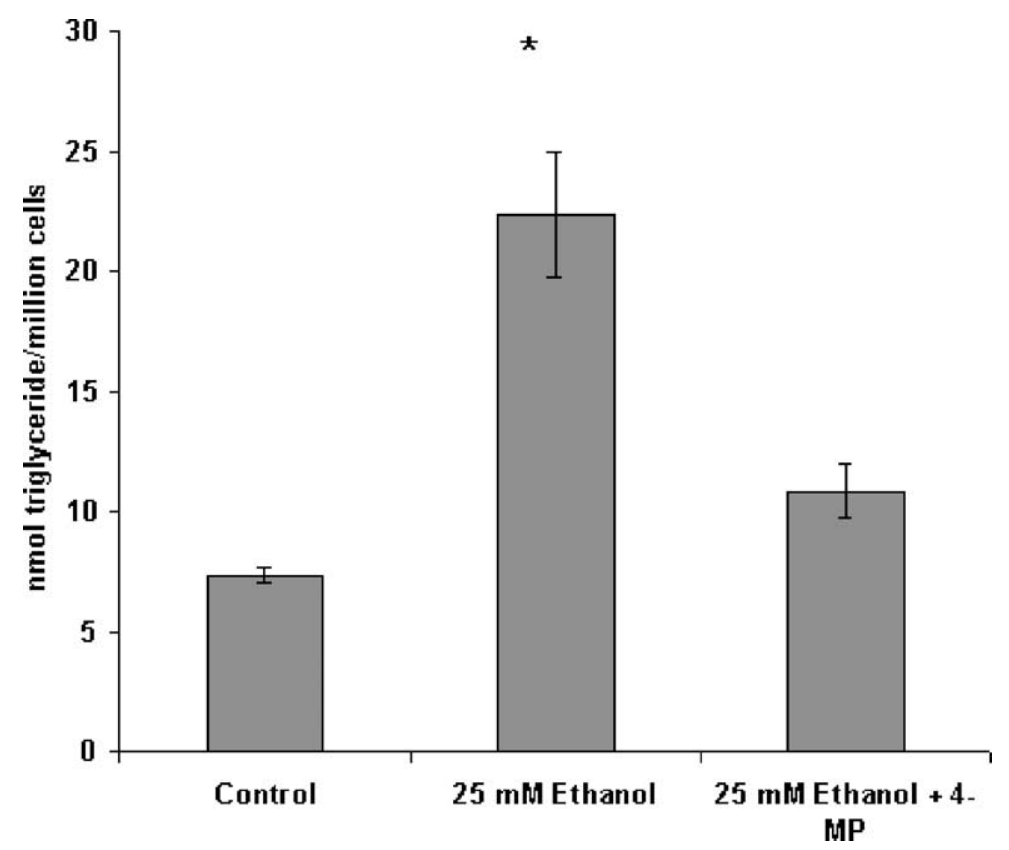

Fig. 4. Elevation of triglyceride in WIF-B cells treated with $25 \mathrm{mM}$ ethanol. WIF-B cells were cultured for $48 \mathrm{~h}$ in the absence or presence of $25 \mathrm{mM}$ ethanol, or $25 \mathrm{mM}$ ethanol and $0.5 \mathrm{mM}$ 4-MP. Triglyceride levels were determined as described in Section 2. Data are expressed as nanomoles triglyceride per million cells \pm S.E.M. of five separate experiments. ${ }^{*} P<0.01$.

\section{Table 2}

Morphological changes in WIF-B cells due to ethanol metabolism

\begin{tabular}{lccc}
\hline Morphological phenomena & Control & $25 \mathrm{mM}$ ethanol & $25 \mathrm{mM}$ ethanol $+0.5 \mathrm{mM} 4-\mathrm{MP}$ \\
\hline Bile canaliculi/100 cells & $49.56 \pm 1.8$ & $33.32 \pm 2.48^{\mathrm{a}}$ & $55.12 \pm 2.84$ \\
Cells containing projections $/ 100$ cells & $6.84 \pm 0.64$ & $22.37 \pm 2.02^{\mathrm{a}}$ & $12.36 \pm 1.45^{\mathrm{b}}$ \\
Cell diameter $(\mu \mathrm{m})$ & $33.95 \pm 0.36$ & $41.68 \pm 0.50^{\mathrm{a}}$ & $32.08 \pm 0.31$ \\
\hline
\end{tabular}

WIF-B cells were cultured for $48 \mathrm{~h}$ in the absence (control) or presence of $25 \mathrm{mM}$ ethanol or $25 \mathrm{mM}$ ethanol $+0.5 \mathrm{mM}$ 4-MP, and were analyzed as described in Section 2. The results shown are from four separate experiments, analyzing three random fields for each experiment.

a $25 \mathrm{mM}$ ethanol is significantly different from both the control and the $25 \mathrm{mM}$ ethanol $+4-\mathrm{MP} ; P<0.01$.

${ }^{\mathrm{b}} 25 \mathrm{mM}$ ethanol + 4-MP is significantly different from control; $P<0.01$. 

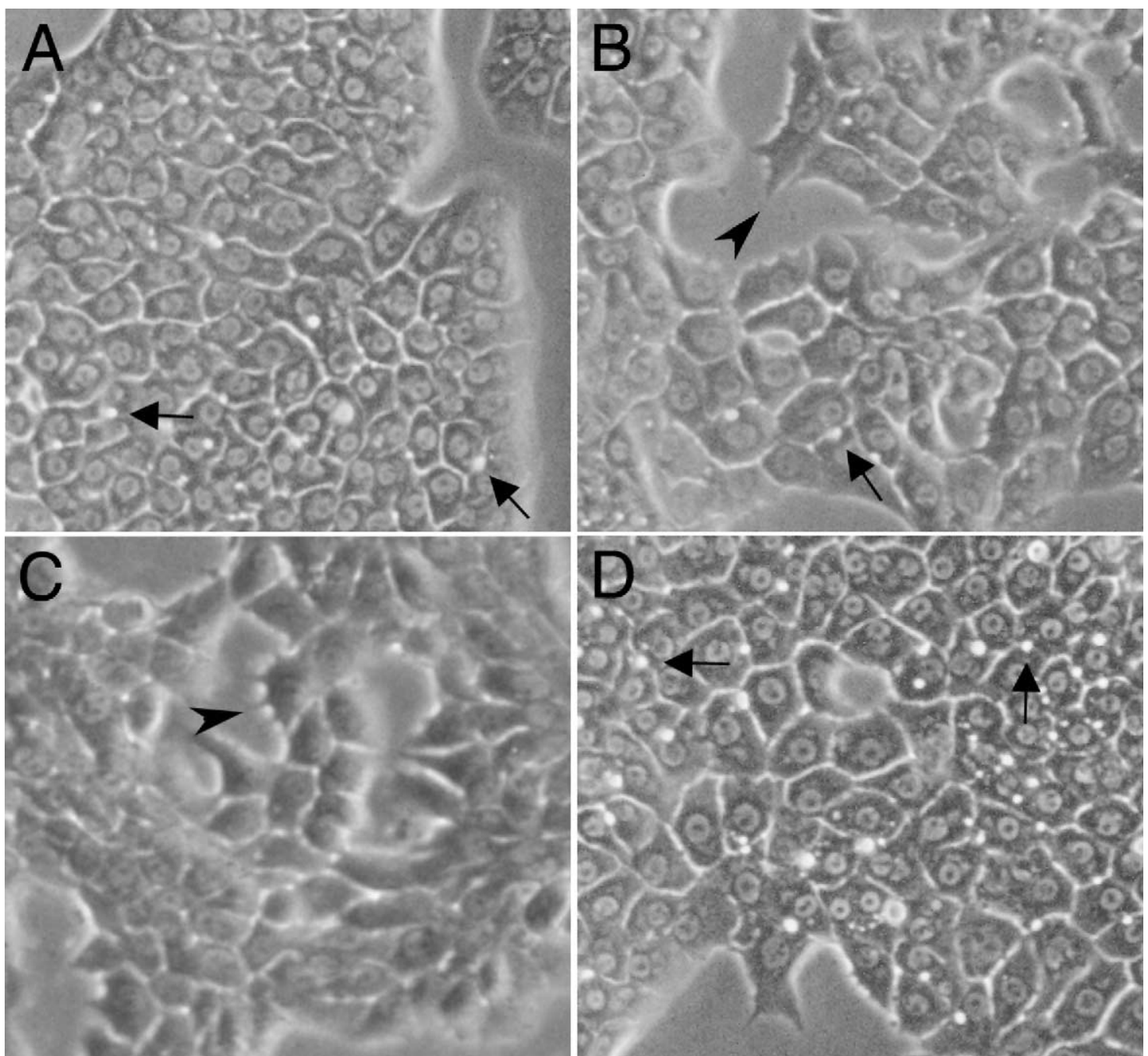

Fig. 5. Morphological differences in WIF-B cells caused by ethanol metabolism. WIF-B cells were cultured $48 \mathrm{~h}$ in the absence of ethanol (A), the presence of $25 \mathrm{mM}$ ethanol (B), the presence of $50 \mathrm{mM}$ ethanol (C), or the presence of $25 \mathrm{mM}$ ethanol and $0.5 \mathrm{mM} 4-\mathrm{MP}$ (D). Phase contrast photographs were taken at random on a Nikon TMS inverted microscope under $20 \times$ magnification. Arrows point to bile canaliculi and arrowheads point to cells containing projections. Photographs are representative of four separate experiments.

(Table 2, Fig. 5D). Incubation of WIF-B cells in the presence of $0.5 \mathrm{mM} 4-\mathrm{MP}$ alone had no observed morphological effects (data not shown). These results are in accordance with previous studies that noted impaired bile canaliculi formation in hepatocytes exposed to ethanol [34,35].

\section{Discussion}

A major difficulty in studying the mechanisms of ethanol-induced hepatocyte defects in function and morphology is that cultured hepatocytes lose many liver-specific functions, such as ADH expression and ethanol metabolism [28]. In an effort to obtain in vitro models to elucidate the mechanisms underlying ethanol-induced hepatocyte injury, many hepatic and non-hepatic cell lines have been examined [3-6]. While the information obtained from these cell lines is very useful for elucidating cellular effects concerning ethanol metabolism, these cell lines are limited in their functional and structural similarities to hepatocytes. These deficiencies limit their usefulness in determining overall effects of ethanol that result in hepatocyte dysfunction. Therefore, an in vitro model that closely resembles normal hepatocytes would be beneficial for elucidating the injury-inducing mechanisms of ethanol. It has been previously established that the WIF-B cell line, a rat hepatoma/human fibroblast hybrid, has many functional and morphological similarities to hepatocytes [713]. This cell line forms functional bile canaliculi, obtains a hepatocyte-like cell polarity, expresses many hepatocytespecific genes, and is stable over many passages. This cell line has been extensively used to study the effects of hepatocyte-specific polarity on intercellular communication, bile acid transport, and protein and membrane trafficking pathways $[8,10-12,40]$.

Experiments were performed on the WIF-B cell line to determine its potential for studying the effects of ethanol 
on hepatocyte functions. Initially, these cells were examined for ADH, ALDH, and CYP2E1 activities and their ability to metabolize ethanol and produce acetaldehyde. These studies showed that the WIF-B cells express active $\mathrm{ADH}$ and CYP2E1 and readily metabolize ethanol. While the level and activity of CYP2E1 in WIF-B cells were relatively low compared to hepatocytes (approximately $25 \%$ ), incubation with the CYP2E1 inducer, 4-MP, increased the level and activity approximately 2.5-fold without affecting WIF-B function or morphology. Even though 4-MP inhibits ADH and CYP2E1 activities, it also increases the level of CYP2E1 [41,42]. Therefore, preincubation of these cells with 4-MP to induce CYP2E1 followed by ethanol treatment in the absence of 4-MP makes this cell line a potential model for studying CYP2E1-mediated effects in ethanol-induced injury.

Since the cells readily metabolized ethanol, the production of acetaldehyde was examined. Acetaldehyde is the metabolite thought to participate in ethanol-induced hepatocyte injury. The concentration and production profile of acetaldehyde in WIF-B cells are very similar to hepatocytes treated with ethanol [24,25]. In addition, examination of the low $K_{\mathrm{m}}$ ALDH in the WIF-B cells revealed its activity was almost identical to that found in hepatocytes, suggesting acetaldehyde was being readily metabolized. These similarities make the WIF-B cell line an appropriate model for studying the role of acetaldehyde in ethanolinduced hepatotoxicity.

The WIF-B cells also exhibit physiologic and morphologic changes in response to ethanol metabolism. Incubation with a modest amount of ethanol $(25 \mathrm{mM})$ for a relatively short period of time $(48 \mathrm{~h})$ resulted in a more reduced redox state and significant accumulation of cellular triglyceride. Notably, these effects were maintained up to $96 \mathrm{~h}$ with no significant changes. These effects are due to ethanol metabolism and are very similar to the reduced redox state and the development of fatty liver in hepatocytes after ethanol exposure [27,39]. Development of fatty liver is speculated to be the first step in developing alcoholic liver disease [24,26,27].

WIF-B cells appear to lose polarity in response to ethanol metabolism, as evidenced by the loss of bile canaliculi and the increase in the number of cells containing projections. Previous studies noted the loss of intercellular communication and impairment in bile canaliculi formation in hepatocytes treated with ethanol [34,35], so the mechanism(s) underlying these changes caused by ethanol may be similar between these two cell types. The morphological changes observed in the WIF-B cells after ethanol treatment may also involve altered cytoskeletal arrangement, leading not only to the observed morphological changes, but also altered functions. In fact, ethanol treatment does affect cytoskeletal architecture in hepatocytes, resulting in defective vesicle transfer, endocytosis, and protein secretion [28-33]. Studies using hepatocytes in vitro have shown that tubulin and actin can be adducted by acetaldehyde, which affects their ability to polymerize and form microtubules and microfilaments, respectively [36-38]. These protein adducts could play a role in the defective cytoskeletal functions observed after ethanol treatment. Key future studies include analyzing the WIF-B cells for these ethanol-induced defects and elucidating the mechanism(s) responsible for the defects.

In summary, the WIF-B cell line, already studied as a model for hepatocyte architecture and function, efficiently metabolizes ethanol and expresses enzymes thought to be responsible for ethanol-induced hepatotoxicity. Treatment of this cell line with a modest amount of ethanol produces many of the same effects found in hepatocytes, including loss of polarity and development of fatty liver. These effects are due to the metabolism of ethanol since cotreatment with ethanol and 4-MP alleviates all of the observed ethanol-induced effects. The results from this study indicate enormous potential for this cell line as a model for studying structural and functional consequences of ethanol-induced hepatocyte injury. The WIF-B cell line holds promise for studies ranging from examination of ethanol-induced protein adducts and CYP2E1-mediated injury to elucidation of the mechanisms responsible for the ethanol-induced hepatic defects in cytoskeletonmediated protein and membrane trafficking. This cell line will also be useful for studies examining the long-term effects of ethanol, which are not currently feasible with cultured hepatocytes.

\section{Acknowledgments}

The authors thank Ann L. Hubbard, Ph.D., for providing the WIF-B cell line and Geoffrey Thiele, Ph.D., Thomas Freeman, Ph.D., and David Rogers for their skillful technical assistance. The Department of Veterans Affairs Alcohol Center supported this work.

\section{References}

[1] Felver ME, Mezey E, McGuire M, Mitchell MC, Herlong HF, Veech GA, et al. Plasma tumor necrosis factor alpha predicts decreased longterm survival in severe alcoholic hepatitis. Alcohol Clin Exp Res 1990;14:255-9.

[2] Gugen-Guillouzo C, Guillouzo A. Modulation of functional activities in cultured rat hepatocytes. Mol Cell Biochem 1983;53/54:35-6.

[3] Clemens DL, Halgard CM, Miles RM, Sorrell MF, Tuma DJ. Establishment of a recombinant hepatic cell line stably expressing alcohol dehydrogenase. Arch Biochem Biophys 1995;321:311-8.

[4] Clemens DL, Forman A, Jerrells TR, Sorrell MF, Tuma DJ. Relationship between acetaldehyde levels and cell survival in ethanol-metabolizing hepatoma cells. Hepatology 2002;35:1196-204.

[5] Galli A, Price D, Crabb D. High-level expression of rat class 1 alcohol dehydrogenase is sufficient for ethanol-induced fat accumulation in transduced HeLa cells. Hepatology 1999;29:1164-70.

[6] Meskar A, Holownia A, Bardou LG, Menez J-F. Effect of acetaldehyde generated from ethanol by ADH-transfected $\mathrm{CHO}$ cells on their membrane fatty acid profiles. Alcohol 1996;13:611-6. 
[7] Shanks MR, Cassio D, Lecoq O, Hubbard AL. An improved polarized rat hepatoma hybrid cell line. Generation and comparison with its hepatoma relatives and hepatocytes in vivo. J Cell Sci 1994;107: 813-25.

[8] Ihrke G, Neufeld EB, Meads T, Shanks MR, Cassio D, Laurent M, et al. WIF-B cells: an in vitro model for studies of hepatocyte polarity. J Cell Biol 1993;123:1761-75.

[9] Decaens C, Rodriguez P, Bouchaud C, Cassio D. Establishment of hepatic cell polarity in the rat hepatoma human fibroblast hybrid WIF B9: a biphasic phenomenon going from a simple epithelial polarized phenotype to an hepatic polarized one. J Cell Sci 1996;109:162335.

[10] Bravo P, Bender V, Cassio D. Efficient in vitro vectorial transport of a fluorescent conjugated bile acid analogue by polarized hepatic hybrid WIF-B and WIF-B9 cells. Hepatology 1998;27:576-83.

[11] Chaumontet C, Mazzoleni G, Decaens C, Bex V, Cassio D, Martel P. The polarized hepatic human/rat hybrid WIF 12-1 and WIF-B cells communicate efficiently in vitro via connexin 32-constituted gap junctions. Hepatology 1998;28:164-72.

[12] Ihrke G, Martin GV, Shanks MR, Shroer TA, Hubbard A. Apical plasma membrane proteins and endolyn-78 travel through a subapical compartment in polarized WIF-B hepatocytes. J Cell Biol 1998; 141:115-33.

[13] Bender V, Bravo P, Decaens C, Cassio D. The structural and functional polarity of the hepatic human/rat hybrid WIF-B is a stable and dominant trait. Hepatology 1999;30:1002-10.

[14] Cassio D, Hamon-Benais C, Guerin M, Lecoq O. Hybrid cell lines constitute a potential reservoir of polarized cells: isolation and study of highly differentiated hepatoma-derived hybrid cells able to form functional bile canaliculi in vitro. J Cell Biol 1991;115:1397-408.

[15] Tuma DL, Zetterman RK, Sorrell MF. Inhibition of glycoprotein secretion by ethanol and acetaldehyde in rat liver slices. Biochem Pharmacol 1980;29:35-8.

[16] Lowry OH, Rosebrough NJ, Farr AL, Randall RJ. Protein measurement with the folin phenol reagent. J Biol Chem 1951;193:265-75.

[17] Folch J, Less B, Sloane-Stanley G. A simple method for the isolation and purification of total lipids from animal tissues. J Biol Chem 1957;226:497-509.

[18] Labarca C, Paigen K. A simple, rapid, and sensitive DNA assay procedure. Anal Biochem 1980;102:344-52.

[19] Wu D, Cederbaum AI. Expression of cytochrome P4502E1 in rat fetal hepatocyte culture. Mol Pharmacol 1996;49:802-7.

[20] Schaffert CS, Sorrell MF, Tuma DJ. Expression and cytoskeletal association of integrin subunits is selectively increased in rat perivenous hepatocytes after chronic ethanol administration. Alcohol Clin Exp Res 2001;25:1749-57.

[21] Lieber CS. Metabolic effects of acetaldehyde. Biochem Soc Trans 1988;16:241-7.

[22] Sorrell MF, Tuma DJ. Hypothesis: alcoholic liver injury and the covalent binding of acetaldehyde. Alcohol Clin Exp Res 1985;9: 306-9.

[23] Volentine GD, Ogden KA, Kortje DK, Tuma DJ, Sorrell MF. Role of acetaldehyde in the ethanol-induced impairment of hepatic glycoprotein secretion in the rat in vivo. Hepatology 1987;7:490-5.
[24] Crow KE, Cornell NW, Veech RL. The rate of ethanol metabolism in isolated rat hepatocytes. Alcohol Clin Exp Res 1977;1:43-7.

[25] Pikkarainen PH, Salaspuro MP, Lieber CS. A method for the determination of "free" acetaldehyde in plasma. Alcohol Clin Exp Res 1979;3:259-61.

[26] Carrasco MP, Marco C, Segovia JL. Chronic ingestion of ethanol stimulates lipogenic response in rat hepatocytes. Life Sci 2001; 68:1295-304.

[27] Lieber CS. Mechanism of ethanol induced hepatic injury. Pharmacol Ther 1990;46:1-41.

[28] Lea MA. Regulation of gene expression in hepatomas. Int J Biochem 1993;25:457-69.

[29] Dalke DD, Sorrell MF, Casey CA, Tuma DJ. Chronic ethanol administration impairs receptor-mediated endocytosis of epidermal growth factor by rat hepatocytes. Hepatology 1990;12:1085-91.

[30] Casey CA, Kragskow SL, Sorrell MF, Tuma DJ. Chronic ethanol administration impairs the binding and endocytosis of asialo-orosomucoid in isolated hepatocytes. J Biol Chem 1987;262:2704-10.

[31] Tworek BL, Tuma DJ, Casey CA. Decreased binding of asialoglycoproteins to hepatocytes from ethanol-fed rats: consequence of both impaired synthesis and inactivation of the asialoglycoprotein receptor. J Biol Chem 1996;271:2531-8.

[32] Sorrell MF, Nauss JM, Donohue TM, Tuma DJ. Effects of chronic ethanol administration on hepatic glycoprotein secretion in the rat. Gastroenterology 1983;84:580-6.

[33] Torok N, Marks D, Hsiao K, Oswald BJ, McNiven MA. Vesicle movement in rat hepatocytes is reduced by ethanol exposure: alterations in microtubule-based motor enzymes. Gastroenterology 1997; 113:1938-48.

[34] Hashieh IA, Mathieu S, Gerolami A. Effects of ethanol on intercellular communications and polarization of hepatocytes in short-term culture. Hepatology 1992;15:751-6.

[35] Hashieh IA, Mathieu S, Besson F, Gerolami A. Inhibition of gap junction intercellular communications of cultured rat hepatocytes by ethanol: role of ethanol metabolism. J Hepatol 1996;24:360-7.

[36] Xu DS, Jennett RB, Smith SL, Sorrell MF, Tuma DJ. Covalent interactions of acetaldehyde with the actin/microfilament system. Alcohol Alcohol 1989;24:281-9.

[37] Tuma DJ, Smith SL, Sorrell MF. Acetaldehyde and microtubules. Ann NY Acad Sci 1991;625:786-92.

[38] Smith SL, Jennett RB, Sorrell MF, Tuma DJ. Substoichiometric inhibition of microtubule formation by acetaldehyde-tubulin adducts. Biochem Pharmacol 1992;44:65-72.

[39] Hoek JB, Cahill A, Pastorino JG. Alcohol and mitochondria: a dysfunctional relationship. Gastroenterology 2002;122:2049-63.

[40] Tuma PL, Nyasae LK, Hubbard AL. Nonpolarized cells selectively sort apical proteins from cell surface to a novel compartment, but lack apical retention mechanisms. Mol Biol Cell 2002;13:3400-15.

[41] Yang M-X, Cederbaum AI. Glycerol increases content and activity of human cytochrome P-4502E1 in a transduced HepG2 cell line by protein stabilization. Alcohol Clin Exp Res 1997;21:340-7.

[42] Wu D, Clejan LA, Potter B, Cederbaum AI. Rapid decrease of cytochrome P-450IIEI in primary hepatocyte culture and its maintenance by added 4-methylpyrazole. Hepatology 1990;12:1379-89. 